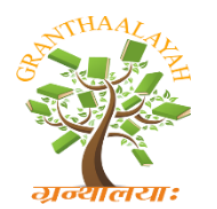

\author{
INTERNATIONAL JOURNAL OF RESEARCH \\ GRANTHAALAYAH \\ A knowledge Repository
}

Science

\title{
A PILOT STUDY IN EKAKUSHTHA W.S.R. TO PSORIASIS WITH SHODHAN CHIKITSA I.E. VAMANA AND VIRECHANA
}

\author{
Dr. Bhavin Derashri ${ }^{* 1}$, Dr. Paresh A. Katariya ${ }^{2}$, Dr.Rupali Gatfane ${ }^{3}$ \\ ${ }^{1}$ Md Scholar Department of Agad Tantra, D. Y. Patil School of Ayurveda and Research Institute. \\ Nerul, Navi Mumbai, India \\ ${ }^{2}$ M.D. (Panchakarma) Assistant Professor Panchakarma Dept. D. Y. Patil School of Ayurveda, \\ Nerul, Navi Mumbai, India \\ ${ }^{3}$ Md (Agad Tantra) Professor Agadtanra Dept. D. Y. Patil School of Ayurveda, Nerul, Navi \\ Mumbai, India
}

\begin{abstract}
The word 'Kushta' is a broad term, which covers almost all the skin diseases. Kushtha is produced invariably by the vitiation of the seven factors i.e. 3 Doshas and 4 Dushyas But different types of pain, colour, shape, specific manifestation etc. are found in Kushtha because of Anshanshakalpana of the Doshas. Accordingly, Charaka explained Kushthas are in fact of innumerable types, but for systemic study they are classified into two major groups 7 Maha Kushtha \& 11 Kshudra Kushtha. Ekakushtha is one of the Kshudra Kushtha. It is the prime among the Kshudra Kushtha, hence Bhavaprakasha mention it as Ekakushtha. Almost all symptoms are vata-kapha predominant \& even tri dosha involvement and for this Shodhana Chikitsa i.e. vamana and virechana are the best line of treatment. We can use these modality as per requirement. Kandu get relieved completely $(100 \%)$ in all both the groups. Low effect was seen in Aswedanam i. e. (33.33\%), Matsyashalklopama was reduced and shows $83.33 \%$ relief, Rukshata shows $91.66 \%$ relief. Highly significant result found after shodhan (Vamana \& Virechana) \& marked improvement was seen in group A \& B. it shows overall ayurvedic modality gives very good result in Ekakushtha.
\end{abstract}

Keywords: Ekakushtha; Psoriasis; Virechana; Vamana.

Cite This Article: Dr. Bhavin Derashri, Dr. Paresh A. Katariya, and Dr. Rupali Gatfane. (2018). "A PILOT STUDY IN EKAKUSHTHA W.S.R. TO PSORIASIS WITH SHODHAN CHIKITSA I.E. VAMANA AND VIRECHANA." International Journal of Research - Granthaalayah, 6(7), 216-222. https://doi.org/10.29121/granthaalayah.v6.i7.2018.1301.

\section{Introduction}

The word 'Kushta' is a broad term, which covers almost all the skin diseases. The word "Kushtha' is derived from - 'Kus nishkarshane' + 'Kta' which implies 'to destroy', 'to scrap out' or to deform, by adding the suffix ' $k$ ta' which stands for firmness or certainty. Thus the word kushtha means that which destroys with certainty. None of the standard texts had mentioned specific etimology 
of Ekakushtha. Only in Bhavprakash, it has been commented that Ekakushtha has been named so, to stress its importance among ksudra kushtha. All kushthas have Tridoshika involvement. It is Vata-kapha predominant disease. So the etiology of Ekakushtha can be understood on the basis of general etiology of Kushtha. Ayurvedic texts have described samanya nidana for all types of Kushtha instead of specific nidanas for any particular type of Kushtha. Thus nidanas can be categorized as follows: - 1. Aharaja - diet and dietetic pattern 2. Viharaja - faulty lifestyle 3. Miscellaneous In the present study, Ekakushtha is compared with psoriasis due to its maximum resemblance with it. Psoriasis is the oldest recorded skin disease. It is one of the most intriguing and perplexing disorder of skin. It is a papulosquamous disorder of the skin, characterized by sharply defined erythematosquamous

Kushtha is produced invariably by the vitiation of the seven factors i.e. 3 Doshas and 4 Dushyas. But different types of pain, colour, shape, specific manifestation etc. are found in Kushtha because of Anshanshakalpana of the Doshas according to Charaka Kushthas are in fact of innumerable types.

Systemic study Kushtha are classified into two major groups 7 Maha Kushtha \& 11 Kshudra Kushtha.

\section{Aims and Objectives}

The study was designed with the following aims and objectives:

- To assess the efficacy of Virechana in Ekakushtha.

- To assess the efficacy of vaman in Ekakushtha.

\section{Samprapti of Kushta}

- Acharyas have not mentioned specific samprapti for each and every kushta, but they have mentioned samanya samprapti for all kinds of kushtas.

- The samanaya samprapti of kushta according to different Acharyas are given below.

\section{Samprapti of Kushta According to Charaka}
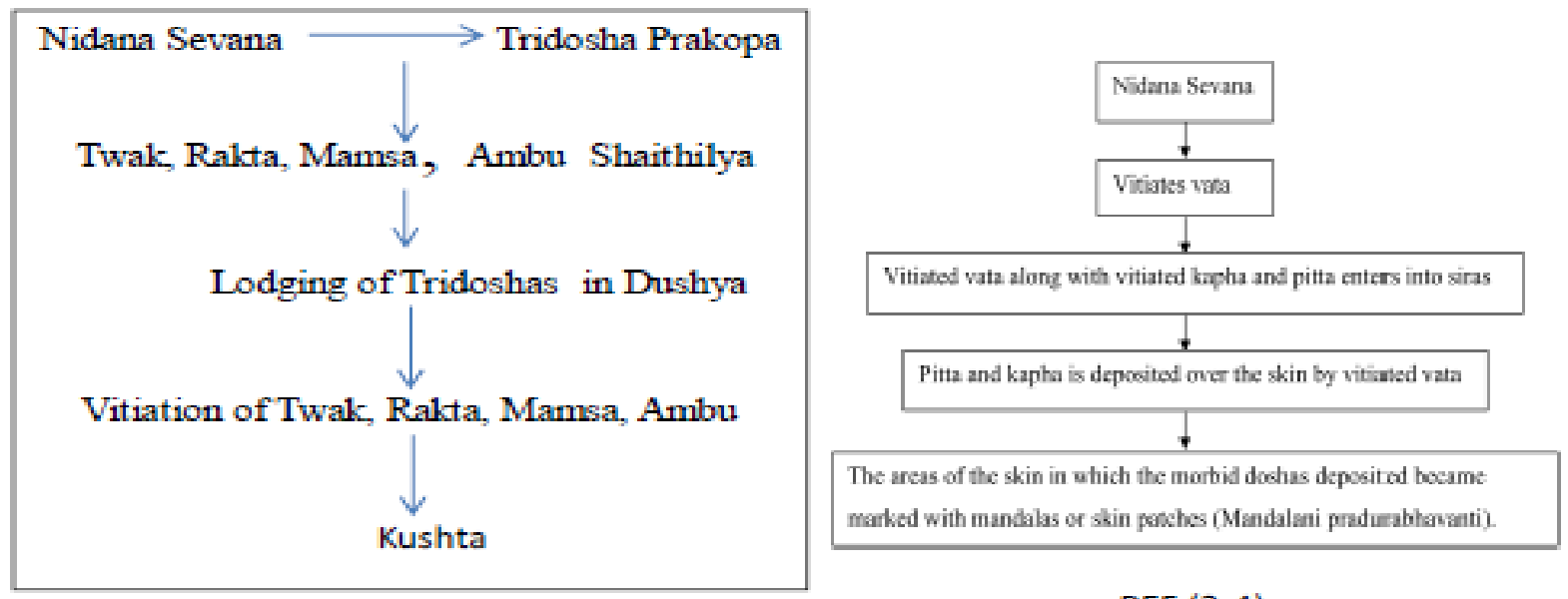

REF (3-4).... 


\section{Samprapti Ghatakas}

Dosha

$$
\begin{array}{ll}
\text { - Tridosha } & \text { - VataKapha Pradhana Pitta. } \\
\text { Dushya } & \text { - Twak, Rakta, Mamsa, Lasika, Ambu. } \\
\text { Srotodushti } & \text { - Sanga and Vimargagamana } \\
\text { Agni } & \text { - Jatharagni and Dhatvagni Mandya } \\
\text { Ama } & \text { - Jataragni, Dhatvagnimadhyajanya } \\
\text { Udbhavasthana - Amashaya, Pakvashaya } \\
\text { Sanchara } & \text { - Tiryaga Sira } \\
\text { Adhisthana } & \text { - Twacha } \\
\text { Vyaktasthana } & \text { - Twacha } \\
\text { Vyadhimarga } & \text { - Bahya } \\
\text { Swabhava } & \text { - Chirakari }
\end{array}
$$

\section{Predominance of Dosha}

\begin{tabular}{|l|l|}
\hline PREDOMINANCE OF DOSHA & KUSHTA TYPES \\
\hline VATA KAPHA & EKAKUSHTA. \\
\hline
\end{tabular}

\section{Discussion}

Ekakushtha is a type of kshudra kushtha which comes under umbrella of kushtha. All Acharya obeys that it is a variety kshudra kushtha. Ekakushtha is vata-kapha predominance Tridoshaja Vyadhi according to Charak. Ekakushtha is comparing as psoriasis due to most of the symptoms of Ekakushtha resembles like psoriasis, i.e. Matschyashakolopamam (Scaling), Mandala (plaque) Aswedana. Many Acharyas, or in some thesis, obeys that Kitibha is psoriasis. But most of cardinal symptoms of psoriasis are not as similar as Kitibha symptoms. So, here Ekakushtha is compared as psoriasis. Ref (6)......

\section{Chikitsa of Kushta}

- Chikitsa is defined as rukpratikriya and roganidana pratikara. However, chikitsa aims not only at radical removal of the causative factors of the disease but also at the restoration of the equilibrium of the bodily humors.

- The general line of treatment of kushta comprises of both yukti vyapashraya and daiva yapashraya but the role of satvavajaya is important. All acharyas opines that kushta chikitsa should be started from its primary stage because a young tree can be cut down easily without much effort while a big well grown tree requires excessive effort. Therefore, Kushta is easily curable in initial stage that becomes difficult to cure or incurable when it reaches the advanced stage.

- Charaka mentions shodhana chikitsa according to the doshic predominance.

- In vata pradhana kushta sarpipana should be done.

- In kapha pradhana kushta vamana should be done.

- In pitta pradhana kushta virechana and raktamokshana should be done.

- A specific periodicity for conducting shodhana karma is mentioned by Susruta, which is supported by most of the other acharyas of Ayurveda. 
- Vamana karma has to be carried out once in a fortnight.

- Virechana once in a month.

- Nasyakarma has to be carried out on every third day if the lesions are localized above the neck.

- Raktamokshana is advocated biannually.

\section{Study Protocol}

- In this study we selected 3 patients of Ekakushatha which shows classical symptoms of Ekakushtha. Also some modern parameters were taken for consideration.

- We did three groups with different treatment modalities.

- 1 st patient (group A) Vamana was given to patient.

- 2 nd patient (group B) Virechana was given to patient.

- 3 rd patient (group C) Vamana and Virechana was carried out.

\section{Materials and Methods}

The patients having classical signs \& symptoms of Ekakushtha (Psoriasis) were selected from the O.P.D. A special Performa including all the aetiological factors of kushtha with dushti lakshanas of dosha, dushya, \& srotas etc. were made for assessing all the patients. The patients were thoroughly questioned and examined on the basis of performa and clinical tests like Auspitz sign, Candle grease were carried out to confirm the diagnosis.

- Sample Size- 03.

- Group A- In this group Vamana was given to patient.

- Group B- In this group Virechana was given to patient.

- Group C- In this group Vamana and Virechana was given to patient.

\section{Study Designed}

\section{Group A- (Vamana)}

- Deepana and Pachana: Tab. Chitrakadi vati (250mg),2 tabs tid, before food, for 3 days.

- Snehana: Arohana Krama snehapana with Pancha tiktha ghritha, starting from $30 \mathrm{ml}$ and was continued till samyak sneha lakshanas are seen. In this patient snehapana was done for 6 days, upto $180 \mathrm{ml}$, by that samyak lakshanas were seen and then mrudu sweda was done, Marichyadi taila was used for abhyanga.

- Vamana: With Madana phaladi yoga (madanaphala pippali(6gm),vacha(5gm), saidhava,madhu),for aakanta pana-ksheera was selected, and Yasti madhu phanat was given after madanaphala yoga.

\section{Group B- (Virechana)}

- Deepana and Pachana: With tab. Chitrakadi vati, (250mg),2-tab tid, before food.

- Snehapana: Arohana karma snehapana with Pancha tiktha ghritha, starting from $30 \mathrm{ml}$ and it was continued for 5 days upto $140 \mathrm{ml}$ and sneha samyak lakshanas were seen, followed by mrudu sweda and marichyadi taila was used for abhyanga.

- Virechana: Abhyadi modaka, 4 tab was given, followed by shunthyadi sheeta jala for anupana. 


\section{Group C}

- Deepana and Pachana: Tab. Chitrakadi vati, (250mg), 2 tabs tid, before food, for 3 days.

- Snehana: Arohana Krama snehapana with Pancha tiktha ghritha, starting from $30 \mathrm{ml}$ and was continued till samyak sneha lakshanas are seen. In this patient snehapana was done for 6 days, upto $200 \mathrm{ml}$, by that samyak lakshanas were seen and then mrudu sweda was done, Marichyadi taila was used for abhyanga.

- Vamana: With Madana phaladi yoga (madanaphala pippali(6gm), vacha(5gm), saidhava, madhu), for aakanta pana-ksheera was selected, and Yasti madhu phanat was given after madanaphala yoga ER 15 DAYS. -

- Deepana and Pachana: With tab. Chitrakadi vati $(250 \mathrm{mg}) 2$ tab tid, before food. For 3 days

- Snehapana: Arohana karma snehapana with Pancha tiktha ghritha, starting from $30 \mathrm{ml}$ and it was continued for 3 days upto $120 \mathrm{ml}$ and sneha samyak lakshanas were seen, followed by mrudu sweda and marichyadi taila was used for abhyanga.

- Virechana: Abhyadi modaka,2 tab was given, followed by shunthyadi sheeta jala for anupana.

\section{Regimen for Patient}

\section{- Pathya}

- Ahara: Laghu Anna, Tikta Shaka, Purana Dhanya, Jangala Mamsa, Mudga, Patola, Food and Ghee prepared with Bhallataka, Triphala and Nimba,Guduchi, Purana Shali,

- Shashtika, Yava, Godhuma, Kordusha, Shyamaka, Udaalaka: Mandukaparni, Bakuchi, Atarushaka, Siddha Ghrita.

- Vihara: Abhyanga with Karanja Taila, Utsadanam with Aaragvadhadi Kashaya,

- Pana, Parisheka, Avagaha etc. with Khadira Kashaya.

\section{- Apathya}

- Ahara: Guru Anna, Amla Rasa, Dugdha, Dadhi, Anupa Matsya, Guda, Tila, Mamsa,

- Taila, Kulattha, Masha, Nishpava, Ikshupishta, Pishta-Vikara, Virudha Bhojana, Adhyashana, Ajirnasana, Vidahi-Abhishyandi Ahara.

- Vihara: Divaswapna, Maithuna, Vegadharana, Paapkarma, Tapa Sevana, Swedana etc.

\begin{tabular}{|c|c|c|c|c|c|c|}
\hline \multirow[t]{2}{*}{$\begin{array}{l}\text { Sings \& } \\
\text { Symptoms }\end{array}$} & \multicolumn{2}{|c|}{$\begin{array}{l}\text { Group A } \\
\text { (VAMAN) }\end{array}$} & \multicolumn{2}{|c|}{$\begin{array}{l}\text { Group B } \\
\text { (VIRECHAN) }\end{array}$} & \multicolumn{2}{|c|}{$\begin{array}{c}\text { Group C } \\
\text { (VAMAN \& VIRECHAN) }\end{array}$} \\
\hline & B. T.\#\# & A. Т.\# & B. T. & A. T. & B. T. & A. T. \\
\hline MATSYASHAKLOPAMAM & 4 & 2 & 4 & 0 & 4 & 0 \\
\hline RUKSHATA & 4 & 2 & 4 & 1 & 4 & 0 \\
\hline ASWEDANAM & 4 & 2 & 4 & 1 & 4 & 1 \\
\hline KANDU & 4 & 0 & 4 & 0 & 4 & 0 \\
\hline
\end{tabular}




\section{Grading of Sings \& Symptoms}

Criteria for Assessment of Overall Effect of the Therapies:

- Complete remission- $76 \%$ to $100 \%$

- Marked improvement- $51 \%$ to $75 \%$

- Mild improvement- $26 \%$ to $50 \%$

- improvement - Below $25 \%$

- No change- $0 \%$

\section{Effect of the Therapies in Percentage}

\begin{tabular}{|c|c|c|c|c|c|c|}
\hline \multirow[t]{2}{*}{$\begin{array}{l}\text { Sings \& } \\
\text { Symptoms }\end{array}$} & \multicolumn{2}{|c|}{$\begin{array}{l}\text { Group A } \\
\text { Vamana }\end{array}$} & \multicolumn{2}{|c|}{$\begin{array}{l}\text { Group B } \\
\text { Virechana }\end{array}$} & $\begin{array}{l}\text { Vain } \\
\text { Vire }\end{array}$ & a \\
\hline & $\begin{array}{l}\text { B. } \\
\text { T. }\end{array}$ & $\begin{array}{l}\text { A. } \\
\text { T. }\end{array}$ & $\begin{array}{l}\text { B. } \\
\text { T. }\end{array}$ & $\begin{array}{l}\text { A. } \\
\text { T. }\end{array}$ & $\begin{array}{l}\text { B. } \\
\text { T. }\end{array}$ & $\begin{array}{l}\text { A. } \\
\text { T. }\end{array}$ \\
\hline MATSYASHAKLOPAMAM & $100 \%$ & $50 \%$ & $100 \%$ & $0 \%$ & $100 \%$ & $0 \%$ \\
\hline RUKSHATA & $100 \%$ & $50 \%$ & $100 \%$ & $25 \%$ & $100 \%$ & $0 \%$ \\
\hline ASWEDANAM & $100 \%$ & $\mathbf{5 0 \%}$ & $100 \%$ & $25 \%$ & $100 \%$ & $25 \%$ \\
\hline KANDU & $100 \%$ & $0 \%$ & $100 \%$ & $0 \%$ & $100 \%$ & $0 \%$ \\
\hline
\end{tabular}

\section{Observations}

It is to seen that patients with vaman and virechana karma get best relif.

\section{Conclusion}

Combination of both shodha is effective in ekkushta.

\section{Result}

Patient with vaman and virechana get best relif in ekkushta.

\section{References}

[1] By Brahma Sankar Mishra, Bhabaprakasha, Eleventh Edition, Chaukhamba Sanskrit Sansthan, Varanasi, 2004, Madhyama khanda, 4/25 P.P.28.

[2] By Tony Burns, Stephene Breathnach, Neil Cox and Christopher Griffiths Rooks, Text book of Dermatology, Volume 2, Seventh Edition, Blackwell Science Publication, Chapter 35 P.P.-35.1. 3

[3] By Dr. Bramhanand Tripathi, Charaka Samhita, Chaukhamba Sanskrit Sansthan, Varanasi, Sutrasthan, 16/20 P.P.323. 4

[4] By Dr. Bramhanand Tripathi, Charaka Samhita, Chaukhamba Sanskrit Sansthan, Varanasi, Chikitsasthan 7/29, P.P.-323. 16. 
[5] By Anantarama Sharma, Srusruta Samhita, Chaukhamba Surabharati Prakashana, Varanasi, 2004, Chikitsasthan 9/6 Vol. 2 P.P.-251

[6] By Acharya Mukundilal Diwivedi, Panchakarma Chikista, Chaukhamba Sanskrit Sansthan, Varanasi, Second chapter, P.P.-67. 11

[7] By Acharya Mukundilal Diwivedi, Panchakarma Chikista, Chaukhamba Sanskrit Sansthan, Varanasi, Fifth chapter, P.P.-323.

[8] By Brahma Sankar Mishra, Bhabaprakasha, Eleventh Edition, Chaukhamba Sanskrit Sansthan, Varanasi, 2004, Madhyama khanda, 4/25 P.P.28 2. By Tony Burns, Stephene Breathnach, Neil Cox and Christopher Griffiths Rooks, Text book of Dermatology, Volume 2, Seventh Edition, Blackwell Science Publication, Chapter 35 P.P.-35.1

*Corresponding author.

E-mail address: drbhavinderashri@gmail.com 